\title{
Serum C reactive protein level in type 2 diabetes mellitus patients attending diabetic clinic in Benin City, Nigeria
}

\author{
Alfred Friday Ehiaghe ${ }^{1^{*}}$, Dennis E. Agbonlahor ${ }^{2}$, Youtchou Mirabeau Tatfeng ${ }^{3}$, \\ Folarin Onikepe $^{3}$, Faith Efosa Oviasogie ${ }^{4}$, Joy Imuetinya Ehiaghe ${ }^{2}$ \\ ${ }^{1}$ Department of Hematology, Igbinedion University, Okada, Nigeria; ${ }^{*}$ Corresponding Author: fredleo2547@yahoo.com \\ ${ }^{2}$ Lahor Research Laboratory, Benin City, Nigeria \\ ${ }^{3}$ Department of Medical Laboratory Science, Niger Delta University, Wilberforce Island, Nigeria \\ ${ }^{4}$ Department of Microbiology, University of Benin, Benin City, Nigeria
}

Received 1 August 2013; revised 2 September 2013; accepted 9 September 2013

Copyright (C) 2013 Alfred Friday Ehiaghe et al. This is an open access article distributed under the Creative Commons Attribution License, which permits unrestricted use, distribution, and reproduction in any medium, provided the original work is properly cited.

\begin{abstract}
C reactive protein is sensitive physiological biomarkers of sub clinical inflammation associated with hyperglycemia. The aim of this study is to determine the fasting serum $C$ reactive protein level in type 2 diabetes mellitus patients attending diabetic clinic in Benin City, Nigeria. The population sample consists of 142 subjects. 71 patients were known type 2 diabetes mellitus, while the other 71 were age matched control subjects. Fasting glucose and $C$ reactive protein were estimated using glucose oxidase method and ELISA method respectively. The age group that has the highest number of type 2 diabetes mellitus was $41-50$ (64\% of males and $36 \%$ of the females). Our finding revealed that $\mathrm{C}$ reactive protein and serum glucose level of type 2 Diabetes mellitus in both females and males show a statistically significant increase as compared with age matched Control subjects, $(P<$ 0.05). An elevation of serum C-reactive protein was demonstrated in both males and females type 2 diabetes mellitus in Benin City, Nigeria. These data support a possible role of inflammatory biomarkers in diabetogenesis.
\end{abstract}

Keywords: C Reactive Proteins; Hyperglycemia; Inflammatory Biomarkers; Diabetogenesis

\section{INTRODUCTION}

The International diabetic federation (IDF) estimated in 2011 that 366 million adults aged 20 - 79 years, of the world's 7 billion population have diabetes mellitus. This gives a comparative prevalence of $8.5 \%$. Since more than $90 \%$ of the global cases of Diabetes mellitus are type 2, it is evident that the epidemic was mainly due to the escalation of the causes of type 2 Diabetes mellitus. According to the current definition, two fasting glucose measurements above $126 \mathrm{mg} / \mathrm{dl}(7.0 \mathrm{mmol} / \mathrm{L})$ are considered diagnostic for Diabetes mellitus or Glycated Hemoglobin (HbA1C) above 6.5\% [1-7].

Nigeria has a population of about 150 million, of which 76 million are adults. Diabetes mellitus related death in 2011 accounted for 63,340 people [1-8]. The classical symptoms of Diabetes are polyuria, polydipsia and weight loss. The causes of most type of diabetes mellitus are multi-factorial: life style, environmental and genetic factors are involved [1-2,9].

$\mathrm{C}$ reactive protein (CRP) is an inflammatory marker produced and released by the liver under the stimulation of cytokines such as tumor necrosis factor- $\alpha$ and interleukins 1 and 6 [10]. Experimental evidence demonstrated that $\mathrm{C}$ reactive protein as a sensitive physiological marker of sub clinical systemic inflammation is associated with hyperglycemia, insulin resistance and overt type 2 Diabetic [11]. Therefore, the aim of this study is to determine the fasting serum C-reactive protein level in type 2 Diabetes mellitus patients attending diabetic clinic in Benin City, Nigeria.

\section{MATERIALS AND METHODS}

\subsection{Study Design}

A cross sectional laboratory based analytical survey was adopted for this research. 


\subsection{Study Area}

This study was carried out in Benin City, Edo State, Nigeria, the two Hospital used were Orobosa Medical Centre and Lahor Medical Centre in Benin City.

\subsection{Sample Size Determination} [12].

The sample size was determined using the formula

$\mathrm{N}=\mathrm{Z}^{2} \times \mathrm{P}(1-\mathrm{P}) / \mathrm{d}^{2}$.

$\mathrm{d}=$ Desired level of significance (0.05).

$\mathrm{Z}=$ Confidence internal (1.96).

$\mathrm{P}=$ Prevalence rate $(8.5 \%)(3)$.

Using this formula, the minimum number of sample will be 71 subjects.

\subsection{Subjects}

The sample population consists of 142 subjects. 71 patients were known type 2 diabetes mellitus and were confirmed to be diabetic using glucose oxidize method [13], while the other 71 were age matched apparently healthy control subject on routine checkup, they were confirmed to be non diabetic using the glucose oxidase method. Ethical Approval and patient consent was obtained from the two centers.

\subsection{Inclusion Criteria}

Both Males and Females were included in this study.

\subsection{Exclusion Criteria}

1) Pregnant women were excluded from this study.

2) Women on oral contraceptives were excluded.

3) Subjects diagnosed with other systemic diseases were excluded from this study.

\subsection{Collection of Blood Samples}

$6 \mathrm{ml}$ of fasting venous blood was collected from the medial cubital vein using vacutainer and needle from each of the subjects and shared equally into a Sodium fluoride Potassium Oxalate container and Plain container.

\section{BLOOD SAMPLE PROCESSING FOR FASTING SERUM C REACTIVE PROTEIN (FSCRP)}

Enzyme Linked Immunosorbent Assay was used in determining the level of $\mathrm{C}$ reactive protein in the serum. The assay employs an antibody specific for $\mathrm{C}$ reactive protein coated on a 96-well plate. Standards and samples are pipetted into the wells and $\mathrm{C}$ reactive protein present in a sample is bound to the wells by the immobilized antibody. The wells are washed and biotinylated anti- human $\mathrm{C}$ reactive protein antibody was added. After washing away unbound biotinylated antibody. Horseradish peroxidase-conjugated streptavidin was pipetted to the wells. The wells are again washed, tetramethylbenzidine substrate Solution was added to the wells and color develops is proportion to the amount of $\mathrm{C}$ reactive protein bound. The Stop Solution changes the color from blue to yellow and the intensity of the color was measured at 450 nm wavelength using Stat Fax ${ }^{\circledR} 4700$ Micro strip Reader. Awareness Technology, Inc. Palm City FL 34991, USA.

\subsection{Fasting Serum Glucose Determination}

\author{
3.1.1. Reagent Composition \\ R1a (Buffer): \\ Phosphate Buffer: $0.1 \mathrm{~mol} / \mathrm{L}, \mathrm{pH}$ 7.0. \\ Phenol: $11 \mathrm{mmol} / \mathrm{L}$. \\ R1b (GOD-PAP Reagent): \\ 4 aminophenazone: $0.77 \mathrm{mmol} / \mathrm{L}$. \\ Glucose Oxidase: $\geq 1.5 \mathrm{kU} / \mathrm{L}$. \\ Peroxidase: $\geq 1.5 \mathrm{kU} / \mathrm{L}$.
}

\subsubsection{Preparation of Working Reagent (Reagent 1)}

Reconstitute the content of one vial of reagent $\mathrm{R} 1 \mathrm{~b}$ with the entire portion of Buffer R1a. The working reagent is stable for 3 months at $+2^{\circ} \mathrm{C}$ to $+8^{\circ} \mathrm{C}$.

\subsubsection{Procedure (Semi Micro Method)}

$10 \mu \mathrm{l}$ of the standard or test sample was added to 1000 $\mu \mathrm{l}$ of Reagent 1 , mixed and incubated for 25 minutes at $20^{\circ} \mathrm{C}$. The absorbance of the standard and the sample was measured against the Reagent blank within 60 minutes at a wavelength of $540 \mathrm{~mm}$ using a Spectrophotometer.

\subsubsection{Study Duration}

Sample collection and processing was from March 2010 to June 2010.

\section{LIMITATION OF THE STUDY}

Subject compliance to Blood samples collection was the limitation to this study.

\subsection{Data Collection}

Data was collected using self administered semi structure questionnaire.

\subsection{Statistical Analysis}

All numerical results were collated from the three groups. Data were presented as Mean \pm Standard Deviation (S.D) and analyzed using one way analysis of variance (ANOVA). Using SPSS version 18.0 P values $<0.05$ were considered significant. 


\subsection{Results}

Of the 142 subject enlisted for the study, 80 (56\%) were males and $62(44 \%)$ were females. The age group that has the highest number of type 2 diabetes mellitus was $41-50$ (64\% of males and $36 \%$ of the females). Closely followed by $31-40$ (50\% of the males and $50 \%$ of the females), Table 1.

Our finding revealed that $\mathrm{C}$ reactive protein and serum glucose level of both females and males type 2 diabetes mellitus shows a statistically significant increase as compared with aged matched control subjects, $(\mathrm{P}<0.05)$ Table 2.

All numerical result was collated from the three groups. Data is presented as mean \pm standard deviation (S.D) and analyzed using one way analysis of variance (ANOVA). Using SPSS version 18.0. $\mathrm{P}$ values $<0.05$ were considered significant $(\mathrm{S}=\mathrm{P}<0.05)$.

\section{DISCUSSION}

Our study revealed that age group that had the highest number of type 2 Diabetes mellitus were $41-51$ (64\% of the Males and $36 \%$ of the Females, Closely followed by $31-40$ (50\% of the males and $50 \%$ of the females), Table 1. These may be due to that type 2 Diabetes mellitus is common among the age bracket. These have been reported by these authors. The International Diabetes Federation (IDF) estimated in 2011 that 366 million adult's age 20 - 79 years, of the world's 7 billion population have Diabetes mellitus. This gives a comparative prevalence of $8.5 \%$. Since more than $90 \%$ of the global cases of diabetes are type 2 , it is evident that the epidemic is mainly due to the escalation of the cases of type 2 Diabetes mellitus and up to $50 \%$ of cases of gestational diabetes mellitus may end up as type 2 diabetes mellitus.
[2-6].

We observed a surge in the serum level of C-reactive protein (CRP) in both males and females type 2 Diabetes mellitus subjects against the aged matched control subjects, $(P<0.05)$, Table 2 . The elevations of CRP may be associated with Systemic inflammation and cardiovascular complication occasioned by Hyperglycemia seen in type 2 Diabetes mellitus. This is in accordance with these findings. Several studies have reported positive association between inflammatory biomarkers and the main factors of Diabetic diagnosis such as Insulin resistance, Hyperglycemia and Glycated Hemoglobin (HbA1C). C-reactive protein (CRP) is the main inflammatory factor that is produced by the liver cells during acute infection or inflammation and its concentration in plasma can increase as much as 1000 fold during injury and infection [14]. Elevated levels of CRP predict the development of type 2 Diabetic. Experimental evidence and some cross sectional data demonstrates that CRP as a sensitive physiological markers of sub clinical systemic inflammation associated with Hyperglycemia, Insulin resistance and overt type 2 Diabetes mellitus [15]. The main physiological abnormalities in type 2 Diabetic are insulin resistance and impaired insulin secretion but some specific underlying determinant of these metabolic defect remain uncertain. It is believe that inflammation have a crucial intermediary role in the pathogenesis of type 2 Diabetic, thereby linking Diabetes mellitus with a number of commonly co-existing condition thought to originate via inflammatory mechanism [16]. Recent research suggests that patients with elevated basal level of CRP are at an increased risk of Diabetes mellitus, Hypertension and Cardiovascular disease [17,18]. Inflammation has a crucial intermediary role in the pathogenesis of type 2 Diabetes mellitus, thereby linking Diabetes melli-

Table 1. Age, sex and type 2 diabetes mellitus (Dm) distribution.

\begin{tabular}{|c|c|c|c|c|c|c|}
\hline Age range (yrs) & Subjects & Males & Females & Type 2 Dm & Type 2 Dm male (\%) & Type 2 Dm female (\%) \\
\hline $15-20$ & 10 & 6 & 4 & 5 & $3(60)$ & $2(40)$ \\
\hline $21-30$ & 32 & 15 & 17 & 11 & $5(45)$ & $6(55)$ \\
\hline $31-40$ & 30 & 16 & 14 & 8 & $4(50)$ & $4(50)$ \\
\hline $41-50$ & 40 & 25 & 15 & 28 & $18(64)$ & $10(36)$ \\
\hline$\geq 50$ & 30 & 18 & 12 & 19 & $10(53)$ & $9(47)$ \\
\hline Total & 142 & $80(56)$ & $62(44)$ & 71 & $40(56)$ & $31(44)$ \\
\hline
\end{tabular}

Table 2. Shows mean \pm standard deviation of FCRP and FSG of type 2 diabetes mellitus patients against control subject.

\begin{tabular}{cccc}
\hline Parameters & Control N $=71$ & Females type 2 diabetes mellitus N=30 & Males type 2 diabetes mellitus N=41 \\
\hline Fasting C reactive proteins (FCRP) $\mathrm{ng} / \mathrm{ml}$ & $0.5 \pm 0.02$ & $102 \pm 0.04^{\mathrm{S}}$ & $104 \pm 0.01^{\mathrm{S}}$ \\
Fasting serum glucose (FSG) $\mathrm{mg} / \mathrm{dl}$ & $85 \pm 0.01$ & $204 \pm 0.04^{\mathrm{S}}$ & $288 \pm 0.02^{\mathrm{S}}$ \\
\hline
\end{tabular}


tus with a number of commonly coexisting condition thought to originate via inflammatory mechanism [14]. Elevated inflammatory biomarkers (CRP) and altered adipokine concentration have been observed in obese type 2 Diabetic patients [19].

\section{CONCLUSION}

An elevation of serum C-reactive protein was demonstrated in both Males and Females type 2 Diabetes mellitus in Benin City, Nigeria. These data support a possible role of inflammatory biomarkers in Diabetogenesis.

\section{REFERENCES}

[1] Hansen, D., Dendale, P.L., Beelen, M., Jonkers, A., Mullens, A. and Coruy, L. (2010) Plasma adipokine and inflammatory marker concentrations are altered in obese, as opposed to non-obese, type 2 Diabetes patients. European Journal Applied Physiology, 109, 397-404. http://dx.doi.org/10.1007/s00421-010-1362-5

[2] International Diabetes Federation (2011) Diabetes atlas. 5th Edition.

[3] World Health organization (1997) Expert committee on the diagnosis and classification of diabetes mellitus: Report on the diagnosis and classification of diabetes mellitus. Diabetes Care, 20, 1183-1197.

[4] World Health Organization (2003) Expert committee on the diagnosis and classification of diabetes mellitus. Follow up report on the diagnosis of diabetes mellitus. Diabetes Care, 26, 3160-3167. http://dx.doi.org/10.2337/diacare.26.11.3160

[5] Chinenye, S., Uchenna, D.I., Unachukwu, C.N., Ogbera, A.O. and Ojule, A.C. (2008) The pattern of diabetes mellitus in Rivers State, Nigeria. Nigeria Endocrine Practice, 2, 87-93.

[6] Motala, A.A. (2002) Diabetes trends in Africa. Diabetes Metabolism Research Review, 18, 514-520. http://dx.doi.org/10.1002/dmrr.284

[7] Vigan, S. (2010) Type 2 diabetes. Annals of Internal Medicine, 152, 31

[8] Sayolah, S.H., Miret, M., Sung, J., Varas, C., Gause, D. and Brancati, F.L. (2001) Post challenge hyperglycemia and mortality in a national sample of U.S adults. Diabetes Care, 24, 1397-1402.

http://dx.doi.org/10.2337/diacare.24.8.1397

[9] Motala, A.A., Esterhrizen, T. and Gouwa, E. (2008) Diabetes and other disorders of hyperglycaemia in a South
African Community: Prevalence and associated risk factor. Diabetes Care, 31, 1783-1788.

[10] Shultz, D.R. and Amoid, P.L. (1990) Properties of four acute phase protein: C Reactive protein, serum amyloid. A protein, al-acid glycoprotein and fibrinogen. Arthritis \& Rheumatism, 20, 129-147. http://dx.doi.org/10.1016/0049-0172(90)90055-K

[11] SU, S.C., Pei, D., Hsieh, C.H., Hsiao, F.C., Wu, C.Z. and Hung, Y.J. (2010) Circulating pro-inflammatory cytokines and adiponectic in young men with type 2 diabetes. Acta Diabetologica, 14, 190-200.

[12] Naing, L., Winn, T. and Rusli, B.N. (2006) Practical issues in calculating the sample size for prevalence studies. Archives of Orofacial Sciences, 1, 9-14.

[13] Barham, D. and Trinder, P. (1972) An improved colour reagent for the determination of blood glucose by the oxidase system. Analyst, 97, 142. http://dx.doi.org/10.1039/an9729700142

[14] Festa, A., Agustino, R.D., Howard, G., Mykkanen, L., Tracy, R.P. and Haffner, S.M. (2000) Chronic sub-clinical inflammation as part of the insulin resistance syndrome. The insulin resistances atherosclerosis study (IRAS). Circulation, 102, 42-47. http://dx.doi.org/10.1161/01.CIR.102.1.42

[15] Pradhan, A.D., Manson, J.E., Rifai, N., Buring, J.E. and Ridker, P.M. (2001) C-reactive protein, interleukin 6 and risk of developing type 2 diabetes mellitus. JAMA, 286, 327-334. http://dx.doi.org/10.1001/jama.286.3.327

[16] Dehghan, A., Kardys, I., de Maat, M.P., Uitterlinden, A.G., Sijbrands, E.J., Bootsma, A.H., Shjnen, T., Hofman, A., Schram, M.T. and Witteman, J.C. (2007) Genetic variation, C-reactive protein level and incidence of diabetes Diabetes, 56, 872-878. http://dx.doi.org/10.2337/db06-0922

[17] Hansen, D., Dandale, P., Beelen, M., Jonkers, R.A., Mullens, A. and Corluy, L. (2010) Plasma adipokine and inflammatory marker concentrations are altered in obese, as opposed to non-obese, type 2 diabetes patients. European Journal of Applied Physiology, 109, 297-404. http://dx.doi.org/10.1007/s00421-010-1362-5

[18] Cleafield, M.B. (2005) C-reactive protein: A new assessment tool for cardiovascular disease. The Journal of the American Osteopathic Association, 105, 409-416.

[19] Shahedi, V., Eizadi, M., Imanipour V. and Seyedhoseini, M.A. (2011) Association of C-reactive protein with insulin resistance in type 2 diabetic. 2011 International Conference on Bioscience, Biochemistry and Bioinformatics, 5, 407-409. 